\title{
Water holding capacity of litter and soil organic matter in mixed prairie and fescue grassland ecosystems of Alberta
}

\author{
M.A. NAETH, A.W. BAILEY, D.S. CHANASYK, AND D.J. PLUTH
}

\section{Abstract}

Litter and organic matter accumulations can reduce soil water through interception of precipitation and subsequent evaporation of absorbed water. Interception varies with mass and water holding capacity (WHC) of litter and organic matter, and is highest from small precipitation events. WHC varies with vegetation type, which is affected by grazing regime. Thus long-term grazing could affect WHC of litter and organic matter and would be important in the hydrologic assessment of rangelands subjected to many small precipitation events throughout the growing season.

The study was conducted in mixed prairie, parkland fescue, and foothills fescue grasslands in Alberta, Canada. Grazing regimes were of light to very heavy intensities, grazed early, late, and continuously during the growing season. Litter and organic matter were sorted by sieving into various sized categories. Litter-soil cores were also evaluated.

WHC of litter and organic matter was lower in mixed prairie than in fescue grasslands. WHC increased with increased particle size, being higher for roots and standing and fallen litter than for organic matter. WHC of large particle-sized material decreased with heavy intensity and/or early season grazing. WHC was affected more by intensity than season of grazing. Grazing affected WHC through species composition changes, since species have different WHC, and through trampling which affected particle size. It was concluded that litter and organic matter WHC were important in rangeland hydrologic assessments.

Key Words: interception, grazing intensity, field capacity, rangeland hydrology

Litter can reduce the amount of water reaching the soil surface through interception of precipitation and subsequent evaporation of absorbed water. Interception losses from small storms are generally high while those from larger storms are under $10 \%$ (Corbett and Crouse 1968, Couturier and Ripley 1973). Interception in grasslands varies with plant species. Interception losses by big bluestem (Andropogon gerardi Vitman) range from 57 to $84 \%$ of simulated precipitation applied for 30 minutes at 3 to $25 \mathrm{~mm}$ and interception losses by buffalograss (Buchloe dactyloides Nutt. Engelm.) were 17 to $74 \%$ of simulated rainfall at 3 to $13 \mathrm{~mm}$ for 30 minutes (Clark 1940). Percent of annual precipitation lost through interception by grasses was $56 \%$ by Kentucky bluegrass ( Poa pratensis L.) (Haynes 1940), 13 to $19 \%$ by a South African veld dominated by Themeda spp. and Cymbopogan spp. (Beard 1956), 26\% by California grassland composed of Avena, Stipa, Lolium, and Bromus species (Kittredge 1948), $10.8 \%$ by curlymesquite (Hilaria belangeri Steud), and $18.1 \%$ by sideoats grama (Bouteloua curtipendula Torr.) (Thurow et al. 1987). Couturier and

\footnotetext{
Authors are research associate, Department of Soil Science; professor, Department of Plant Science; professor, Department of Soil Science; and professor, Department of Soil Science, University of Alberta, Edmonton, Alta.,Canada, T6G 2E3. At the time of the research, the senior author was a Ph.D. graduate student, Department of Plant Science, University of Alberta.

The authors wish to acknowledge the financial support of NOVA Corporation of Alberta. K. Ostermann, V. Naeth, J. Quinn, J. McGill, G. Hoppe, and D. White are thanked for their technical assistance. The Lethbridge Research Station of Agriculture Canada, the Eastern Irrigation District, and the University of Alberta are acknowledged for the use of their long-term grazing treatments.

Manuscript accepted 10 May 1990.
}

Ripley (1973) calculated net interception losses by mixed prairie grasses at 14 to $24 \%$. The amount of water subsequently evaporated is governed primarily by the mass of accumulated litter (Helvey and Patric 1965), water holding capacity (WHC) of litter, and evaporation potential before and after the precipitation event (Corbett and Crouse 1968). WHC of litter varies with vegetation type, with that of litter in grasslands ranging from 0.5 to $8.4 \mathrm{~mm}$ (Flory 1936, Weaver and Rowland 1952, Burgy and Pomeroy 1958, Corbett and Crouse 1968). Thurow et al. (1987) reported WHC of $114 \%$ for curlymesquite and $81 \%$ for sideoats grama in Texas.

Grazing regimes facilitating accumulation of litter and organic matter could reduce mineral soil water due to retention of precipitation above-ground and subsequent evaporative loss. However the increased infiltration capacity and reduced evaporation from the soil surface from such accumulations and the reductions in evapotranspiration due to defoliation from grazing will generally more than offset this (Lowdermilk 1930, Weaver and Rowland 1952). In rangelands of the Northern Great Plains where many small precipitation events occur throughout the growing season, precipitation not contributing to soil water because it was intercepted and evaporated could be significant. It was hypothesized that WHC of litter and organic matter would be affected by its particle size distribution and thus grazing regimes facilitating accumulation of litter or organic matter of sizes which had high water holding capacities would reduce soil water the most. It was further hypothesized that overall water holding capacity would differ with ecosystem as affected by plant species composition.

If long-term grazing affects WHC of litter and organic matter and leads to reductions in soil water, these reductions will be important in the hydrologic assessment of rangelands subjected to many small precipitation events throughout the growing season and should be considered in management and modelling. Thus a study was initiated in mixed prairie and fescue grasslands of Alberta, Canada, with the objectives (1) to determine whether WHC of litter and organic matter is affected by ecosystem, (2) to determine whether particle size of litter and organic matter affected WHC, and (3) to determine the effect of season and intensity of grazing on WHC of litter and organic matter.

\section{Materials and Methods}

\section{Study Sites}

Three study sites representing major rangeland ecosystems of southern and central Alberta were selected. Each site had longterm grazing treatments, ungrazed controls, grass-dominated vegetation that had never been cultivated, and slopes of less than 2\% (Naeth 1988).

The mixed prairie site was located near Brooks approximately $225 \mathrm{~km}$ east of Calgary $\left(51^{\circ} \mathrm{N}\right.$ and $\left.112^{\circ} \mathrm{W}\right)$. The area has a continental prairie climate and a semiarid moisture regime. Mean annual precipitation is $355 \mathrm{~mm}$. Mean annual temperature is $4^{\circ} \mathrm{C}$, with a July mean of $19^{\circ} \mathrm{C}$ and a January mean of $-14^{\circ} \mathrm{C}$. Elevation averages $745 \mathrm{~m}$ above sea level with slopes of less than $2 \%$. Soils are Brown Solodized Solonetz and Brown Solod (Natriboroll) deve- 
loped on till (Kjearsgaard et al. 1982). Vegetation is of the Blue grama-Spear grass-Wheat grass (Bouteloua-Stipa-Agropyron) faciation, dominated by blue grama grass (Bouteloua gracilis Lag.), spear grass (Stipa comata Trin. \& Rupr.), and western and northern wheatgrasses (Agropyron smithii Rydb. and dasystachyum Hook.). Pasture sage (Artemisia frigida Willd.) and little clubmoss (Selaginella densa Rydb.) are common forbs. A short grass disclimax dominated by blue grama is common as a result of heavy long-term grazing.

The parkland fescue site was located near Kinsella approximately $150 \mathrm{~km}$ southeast of Edmonton $\left(53^{\circ} \mathrm{N}\right.$ and $\left.111^{\circ} \mathrm{W}\right)$. The cimate is dry subhumid. Mean annual precipitation is $422 \mathrm{~mm}$. Mean annual temperature is $2^{\circ} \mathrm{C}$ with a July mean of $17^{\circ} \mathrm{C}$ and a January mean of $-17^{\circ} \mathrm{C}$. Elevation averages $685 \mathrm{~m}$ above sea level with gently rolling to hilly topography (Howitt 1988). Grassland soils are dominated by Orthic Black Chernozems (Cryoboroll) developed on till. Vegetation consists of grass and shrub communities with aspen groves occurring at irregular intervals. Rough fescue (Festuca hallii Vasey Piper) (Pavlick and Looman 1984) dominates open undisturbed grasslands and western porcupine grass (Stipa curtiseta Hitchc.) co-dominates on grazed areas. Forbs are a common component of the vegetation.

The foothills fescue grassland site was located near Stavely approximately $100 \mathrm{~km}$ south-southwest of Calgary $\left(50^{\circ} \mathrm{N}\right.$ and $114^{\circ} \mathrm{W}$ ). The climate is subhumid without marked deficiency of precipitation. Mean annual precipitation is $550 \mathrm{~mm}$. Mean annual temperature is $5^{\circ} \mathrm{C}$, with a July mean of $18^{\circ} \mathrm{C}$ and a January mean of $-10^{\circ} \mathrm{C}$. Elevation averages $1,350 \mathrm{~m}$ above sea level and topography is gently rolling to hilly. Soils are Orthic Black Chernozems (Haploboroll) developed on till (Johnston et al. 1971). Vegetation is of the fescue grassland association with rough fescue (Festuca campestris Rydb.) dominating in the undisturbed and lightly grazed areas. Parry's oat grass (Danthonia parryi Scribn.) and bluebunch fescue (Festuca idahoensis Elmer) are co-dominants in grazed areas. Under heavy grazing regimes, rough fescue is replaced by annual invaders and bluegrass ( $P o a$ L.) species.

\section{Grazing Treatments}

In mixed prairie, 3 grazing treatments were studied within a community pasture established in 1964: (1) early season grazing from May through July; (2) late season grazing from August through October; and (3) a control ungrazed since the late 1930s. The stocking rate was heavy at $0.9 \mathrm{AUM} \mathrm{ha}^{-1}$.

In parkland fescue, 5 grazing treatments established in 1973 on the University of Alberta ranch were studied: (1) light June grazing from 1 to 30 June at $1.5 \mathrm{AUM} \mathrm{ha}^{-1}$; (2) heavy June grazing from 1 to 30 June at 4.4 AUM ha ${ }^{-1}$; (3) heavy autumn grazing from 15 September to 15 October at $4.4 \mathrm{AUM} \mathrm{ha}^{-1}$; (4) light autumn grazing from 15 September to 15 October at $1.5 \mathrm{AUM} \mathrm{ha}^{-1}$; and (5) a control ungrazed since 1942 (Bailey et al. 1987).

In foothills fescue, 5 grazing treatments established in 1949 on the Agriculture Canada Range Research Substation and grazed May through September were studied: (1) very heavy grazing at 4.8 AUM ha ${ }^{-1}$; (2) heavy grazing at $2.4 \mathrm{AUM} \mathrm{ha}^{-1}$; (3) moderate grazing at $1.6 \mathrm{AUM} \mathrm{ha}^{-1}$; (4) light grazing at $1.2 \mathrm{AUM} \mathrm{ha}^{-1}$; and (5) a control comprised of permanent exclosures in each treatment (Johnston et al. 1971).

\section{Experimental Design and Statistical Analyses}

The experimental design within each site had a hierarchical arrangement of grazing treatment, sample area, and subsamples (Steel and Torrie 1980). Three 0.1 -ha sample areas were randomly established within each treatment.

Statistical analyses were conducted using variation among the 0.1-ha sample areas as a measure of error for testing the significance of treatments. Data were tested for homogeneity of variance using
Cochran and Bartlett-Box tests. The $\mathrm{W}$ test was used to test data for normality of distribution (Shapiro and Wilk 1965). Analysis of variance was used to test for treatment effects. Data with significant $F$ values were further analyzed to separate the means using the Student-Newman-Keul (SNK) test at the 5\% probability level (Steel and Torrie 1980).

In each year by treatment combination, variation among samples was not significantly different from subsamples and, therefore, sample and subsample variation were pooled in further analyses. There was no significant difference within a treatment between study years so data from both years were pooled. Sources of variation in the final statistical analysis were treatments and error within treatments.

\section{Sampling and Analyses}

For this study, litter refers to all dead organic material not incorporated with mineral soil and occurring above soil mineral horizons. Soil organic matter refers to the organic fraction of soil (Canada Department of Agriculture 1979).

At each site, sampling was conducted in late August 1985 and 1986 using 10 randomly located $0.1-\mathrm{m}^{2}$ quadrats in each sample area ( 30 per treatment). Live vegetation, including dried tips of live plants, and standing litter were removed with clippers at ground level. Fallen litter was removed from the soil surface with hand rakes. Soil organic matter was lifted as a slab, after cutting down to a mineral soil horizon where color and textural changes were used to locate the bottom of the Ah horizon. Sampling depths averaged 5 to $8 \mathrm{~cm}$ in mixed prairie (no difference in depth among treatments) and 10 to $15 \mathrm{~cm}$ in parkland fescue (no difference in depth among treatments) and foothills fescue (very heavy treatment shallower than other treatments).

Live vegetative material was oven dried at $65^{\circ} \mathrm{C}$ for 24 hours, then weighed. Litter and organic matter samples were air dried then sorted by size using sieves mounted on an automatic sieve shaker as modified from Coupland (1973). Five minutes of shaking was required to sort the samples without breaking down plant material. Sieves selected on the basis of laboratory trials had openings of $2.0,0.85$, and $0.212 \mathrm{~mm}(9,20$, and 65 mesh Tyler equivalents), with a bottom pan.

The litter and soil organic matter were separated into 6 categories: (1) standing litter collected in the field; (2) coarse litter remaining in the top sieve $(2 \mathrm{~mm})$ and recognizable as undecomposed plant parts; (3) medium litter that was partly decomposed and collected in the second sieve $(0.85 \mathrm{~mm})$; (4) fine organic matter that was relatively decomposed and collected in the third sieve $(0.212$ $\mathrm{mm}$ ); (5) very fine organic matter that was decomposed and collected in the bottom pan; and (6) roots visibly greater than $0.2 \mathrm{~mm}$ which were removed from the above samples. Categories 4 and 5 contained most smaller roots and root hairs. Above-ground organic matter comprised standing, coarse, and medium litter, and live vegetation. Below-ground organic matter comprised roots, and fine and very fine organic matter. Total organic matter included all above categories.

In 1985 and 1986, 9 soil and litter samples to a depth of $76 \mathrm{~mm}$ were taken from each treatment with a $76 \mathrm{~mm}$ diameter Uhland core sampler. The top of the core corresponded to the top of the fallen litter layer. These cores were used to determine WHC of litter and organic matter in a relatively undisturbed state and thus a truer reflection of treatment effect.

\section{Determination of Water Holding Capacity}

Water holding capacity (WHC) of litter and soil organic matter was determined with modifications to methods outlined by Kittredge (1955) and Bernard (1963). After sorting of the samples collected each year, 5 randomly selected samples from each litter and soil organic matter category from each 0.1 -ha sample area was 
used to fill $7 \mathrm{~cm}$ high by $7 \mathrm{~cm}$ diameter plastic cylinders to a standard weight ( 15 per treatment). Cotton fabric secured with a rubber band was used to cover the cylinder bottom. Cylinders were

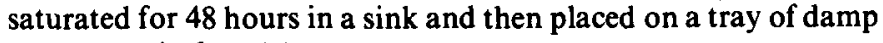
sand to drain for $\mathbf{4 8}$ hours.

The sand mixture used for drainage was $11 \%$ gravel, $23 \%$ very coarse sand, $38 \%$ coarse sand, $22 \%$ medium sand, and $6 \%$ fine and very fine sand as determined by dry sieving (McKeague 1978). Prior to samples being placed on it, the sand was put in a large plastic tray with a drainage spout for water, saturated with water and drained for 48 hours. Water content of sand at the time litter and organic matter samples were placed on it was $10.8 \%$ (SD $2.1 \%$ ). After the cylinders drained for 48 hours, water content of the sand was $14.0 \%$ (SD 2.4\%). Laboratory temperature was maintained at approximately $18^{\circ} \mathrm{C}$ and relative humidity at approximately $35 \%$. Trays were covered with plastic to prevent evaporation and create a stable microenvironment.

After draining on the sand, the samples were weighed and oven dried at $105^{\circ} \mathrm{C}$ for 48 hours then re-weighed. Water holding capacity for each sample was determined by subtracting oven dry mass of its cylinder contents from its drained mass, dividing by oven mass, and multiplying by 100 ( $\mathrm{g}$ water $/ \mathrm{g}$ litter (o.d.w.) $\times 100=$ $\%$ WHC). Uhland core samples were treated in the same manner.

\section{Results}

Within a treatment, WHC of litter and soil organic matter did not generally differ significantly with year, and plotted data are means of years. At all 3 sites, WHC of roots, standing litter, and coarse organic matter were higher than that of medium, fine, and very fine organic matter (Figs. 1, 2, and 3). WHC was generally

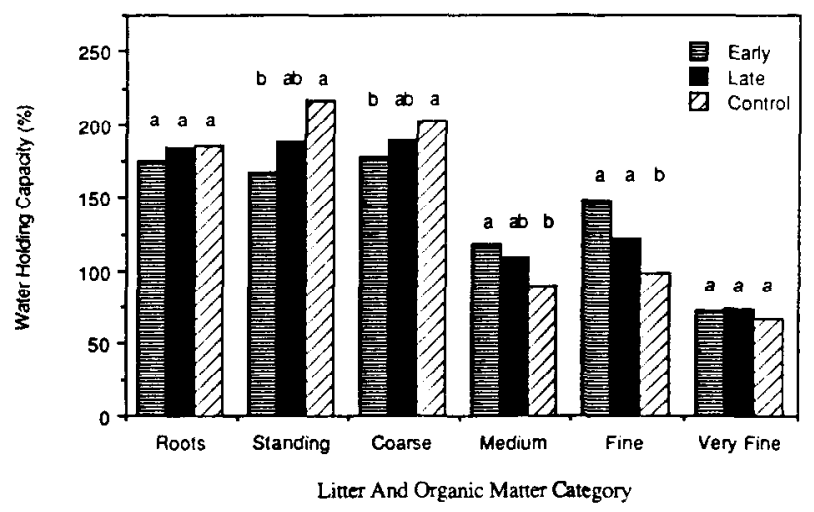

Fig. 1. Water holding capacity of roots, litter, and organic matter in mixed prairie. Within category, means with the same letters are not significantly different $(P<0.05)$.

higher in fine than in medium or very fine organic matter.

WHC of mixed prairie roots, standing litter, and coarse organic matter ranged from 172 to $216 \%$ and that of fine, medium, and very fine organic matter from 68 to $148 \%$ of oven dry weight (Fig. 1). In parkland fescue, WHC of roots, standing litter, and coarse organic matter ranged from 180 to $258 \%$ and that of medium, fine, and very fine organic matter ranged from 78 to $148 \%$ (Fig. 2). In foothills fescue, WHC of roots, standing litter, coarse, and fine organic matter ranged from 200 to $254 \%$, while that of medium and very fine organic matter ranged from 107 to $139 \%$ (Fig. 3).

WHC of undisturbed cores was affected more by intensity of grazing than by season of grazing (Table 1). In both fescue grasslands, WHC of cores was lower in heavy and very heavy treatments than in control or moderate treatments. In mixed prairie WHC did not differ significantly with treatment. WHC was highest in foothills fescue and lowest in mixed prairie.

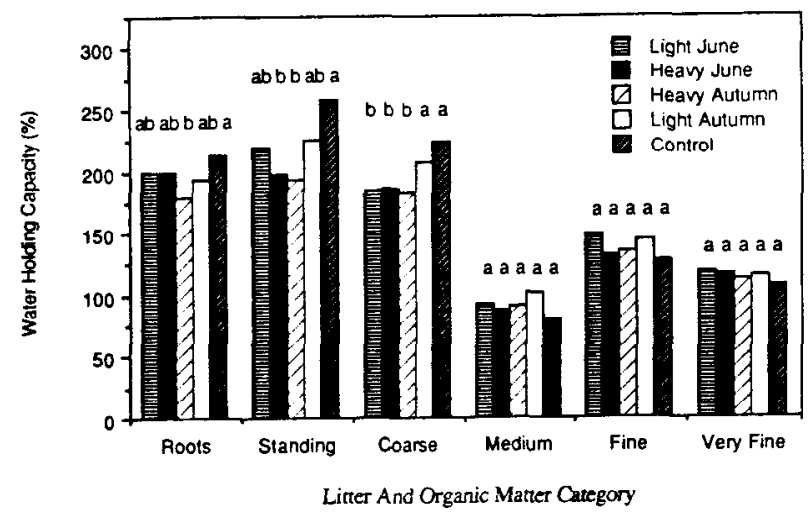

Fig. 2. Water holding capacity of roots, litter, and organic matter in parkland fescue. Within category, means with the same letters are not significantly different $(P<0.05)$.

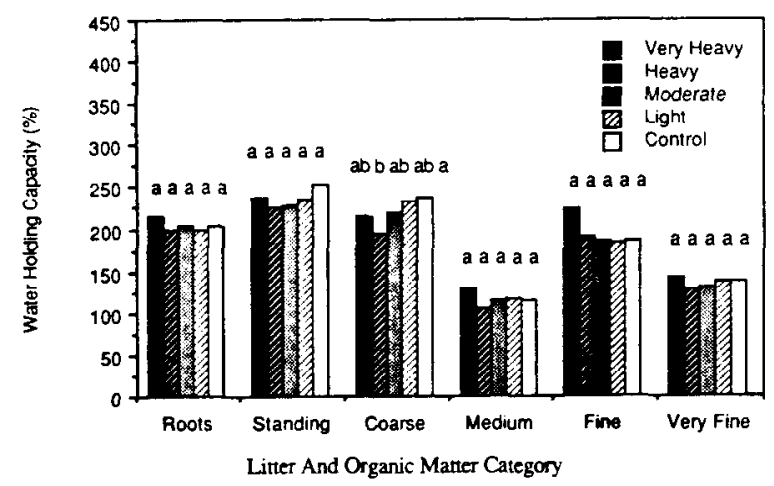

Fig. 3. Water holding capacity of roots, litter, and organic matter in foothills fescue. Within category, means with the same letters are not significantly different $(P<0.05)$

Grazing effects on WHC of litter and organic matter varied with site. At all 3 sites, coarse organic matter tended to have higher WHC in cont rols and light intensity and/or late season treatments such as light autumn in parkland fescue. WHC of coarse organic matter was lowest in heavy intensity and/or early season treatments. WHC of standing organic matter was affected by grazing treatment being highest in controls and lowest in early season and/or heavy intensity treatments.

Although not tested in this study, there was visual evidence of

Table 1. Water holding capacity of undisturbed litter and soil core samples (76 mm diameter and depth) at the study sites.

\begin{tabular}{llc}
\hline \hline Site & $\begin{array}{l}\text { Grazing } \\
\text { Treatment }\end{array}$ & $\begin{array}{c}\text { Water Holding } \\
\text { Capacity (\%) }\end{array}$ \\
\hline Mixed & Early Season & $42 \mathrm{a}$ \\
Prairie & Late Season & $35 \mathrm{a}$ \\
& Control & $43 \mathrm{a}$ \\
\hline & Light June & $69 \mathrm{ab}$ \\
Parkland & Heavy June & $61 \mathrm{~b}$ \\
Fescue & Heavy Autumn & $64 \mathrm{~b}$ \\
& Light Autumn & $74 \mathrm{ab}$ \\
& Control & $84 \mathrm{a}$ \\
\hline & Moderate & $133 \mathrm{a}$ \\
Foothills & Heavy & $130 \mathrm{~b}$ \\
Fescue & Very Heavy & $124 \mathrm{c}$ \\
\hline
\end{tabular}

Within site, treatment means with the same letters are not significantly different $(P<0.05)$. 
hydrophobicity when wetting the litter and organic matter. Organic substances adsorbed on mineral particles were reported to confer hydrophobic properties on mineral soils (Debano and Letey 1969), reducing WHC.

\section{Discussion}

WHC of roots, standing litter, and coarse organic matter were higher than those of medium, fine, and very fine organic matter because of larger amounts of material in a relatively undecomposed state in these former fractions. This is best explained by the work of Farmer (1978), who reported that soil organic matter occurs in 2 forms: discrete, largely organic particles and a molecular form on mineral surfaces. At saturation, the large organic particles with a wide range of pores hold up to twice as much water per volume as mineral soils. More highly decomposed organic matter of the molecular form would hold less water due to less pore space and adhesion in molecular form. Although very fine organic particles would have a greater surface area than larger particles and therefore hold more water, the higher porosity of the larger particles tends to offset this. The higher WHC of fine organic matter compared to medium and very fine organic matter is also related to particle size. The fine organic matter category contains the majority of small roots and root hairs and is thus largely in a relatively undecomposed state, capable of holding more water than the largely molecular organic matter in the medium and very fine categories.

Grazing treatment effects on WHC reflect changes in species composition caused by grazing and the effect of treading on litter decomposition rate. Soil characteristics had less effect since there were no significant within-site soil textural differences (Naeth 1988). There were no significant differences in soil bulk density among cores in mixed prairie (Naeth 1988). Significant differences did occur in both fescue grasslands. However, resulting differences in soil porosity contributed only a small fraction to the resultant WHC compared to diffrences attributable to litter. WHC of litter varies with grassland vegetation (Flory 1936, Weaver and Rowland 1952, Burgy and Pomeroy 1958, Corbett and Crouse 1968) and there were major vegetation changes due to grazing in mixed prairie (Naeth 1985), parkland fescue (Bailey et al. 1987), and foothills fescue (Johnston 1961, Johnston et al. 1971). Since grazing effects on WHC occurred where the greatest species composition differences were found - the control and early season grazing in mixed prairie, the control and heavy grazing in parkland fescue, and the control and light grazing compared to heavy grazing in foothills fescue-it can be stated that grazing affects WHC of litter and organic matter. This is partly explained by different cellulose and lignin contents of different species resulting in different decomposition rates (Norman 1933). Higher WHC of organic matter in the control is in part due to the absence of trampling which can break litter into smaller pieces, create better litter-soil contact, and facilitate more rapid decomposition (McCalla 1943). Thus there will be more large particle-sized litter in the control contributing to higher WHC. Zeller (1963) also found higher amounts of decomposed litter than fresh litter in grazed grasslands.

WHC in this study represents maximum available storage and the upper limits for precipitation held in organic matter mass. Although some differences in WHC of individual litter and organic matter categories occurred among grazing treatments, the overall effect of grazing on WHC of litter and organic matter in mixed prairie is likely small, since differences in WHC of whole cores were not detected in any treatment. In the fescue grasslands, whole core values show WHC of organic matter generally declines with heavy intensity grazing. From a soil conservation perspective this may be contradictory in that light grazing, which improves overall hydrologic condition (Naeth 1988), can lead to accumulation of organic matter with higher WHC. However, the more beneficial effects of holding water as opposed to its running off the soil surface would tend to negate the higher WHC. Similar conclusions have been made by Lowdermilk (1930) and Weaver and Rowland (1952). The lack of significant grazing treatment effects on WHC of organic matter would indicate grazing treatment would not affect overall below-ground WHC. However, the higher WHC in the coarse litter in parkland fescue under light autumn grazing and in the control, and in the heavy grazing treatment in foothills fescue would indicate the above-ground litter would have the greatest effect on overall WHC. This is evidenced by the often lower surface soil water contents in the controls than in the grazed treatments for the study sites (Naeth 1988).

McCalla (1944) found decreases in dry weight and volume of litter were accompanied by increases in wetting speed in initial decomposition stages, which combined with higher WHC of larger sized organic matter, would mean greater absorption of precipitation. Greater masses of large sized organic matter per unit land area and higher ground cover in control and light intensity grazing treatments (Naeth 1988) could lead to higher interception and retention than in heavy intensity grazing treatments.

Biomass and cover have also been identified as sources of variation in interception by Clark (1940) and Thurow et al. (1987). Thurow et al. (1987) hypothesized that pilose blades and horizontal growth form of curlymesquite aided water retention, compared to the relatively vertical smooth blades of sideoats grama, but this was offset by a lower standing crop production potential. Thus interception storage capacity was greater for sideoats gramadominated grasslands than for curlymesquite dominated grasslands. Similarly such biomass and growth forms may affect actual field interception and WHC of litter and organic matter in grasslands from this study, with that of mixed prairie vegetation being lower than that of the 2 fescue grasslands.

\section{Conclusions}

(1) WHC of litter and organic matter differed with ecosystem, being lower in mixed prairie than in fescue grasslands.

(2) WHC differed with particle size of litter and organic matter. WHC of large particle-sized litter and organic matter was higher than that of small particle-sized litter and organic matter.

(3) Grazing affected WHC of litter and organic matter with WHC in large particle-sized organic matter decreasing with heavy intensity and / or early season grazing, and WHC of small particlesized organic matter being less affected by grazing treatment. WHC of undisturbed cores was affected more by intensity than season of grazing.

(4) WHC of litter and organic matter, plant species composition, and amounts and kinds of organic matter are all key factors in determining the overall WHC of litter and soil organic matter layers in individual grasslands. WHC must be considered in hydrologic assessments and modelling of rangelands where small storms are a common form of precipitation since they may affect soil water especially in the near surface zone. The amount of large particlesized organic matter relative to small particle-sized organic matter is a critical factor in determining the magnitude of WHC in the 3 grassland ecosystems examined.

\section{References}

Bailey, A.W., M.G. Willoughby, and B.D. Irving. 1987. Effect of grazing on forage and beef production from rough fescue rangeland in central Alberta. Farming for the Future Final Report. Proj. 84-0335.

Beard, J.S. 1956. Results of the mountain home rainfall interception and infiltration project on black wattle, 1953-1954. J. So. Afr. Forest. 27:72-85.

Bernard, J.M. 1963. Forest floor moisture capacity of the New Jersey pine barrens. Ecology 44:574-576. 
Burgy, R.H., and C.R. Pomeroy. 1958. Interception losses in grassy vegetation. Trans. Amer. Geophys. Union. 39:1095-1100.

Canada Department of Agriculture. 1979. Glossary of terms in Soil Science. Can. Dep. Agr. Pub. 1459.

Clark, O.R. 1940. Interception of rainfall by prairie grasses, weeds, and certain crop plants. Ecol. Monog. 10:243-277.

Corbett, E.S., and R.P. Crouse. 1968. Rainfall interception by annual grass and chapparal. USDA Forest Serv. Res. Pap. PSW-48.

Coupland, R.T. 1973. I Dynamics of aboveground standing crop. Tech. Rep. 27. Canadian Comm. for the International Biological Program. Saskatoon, Sask.

Couturier, D.E., and E.A. Ripley. 1973. Rainfall interception in mixed grass prairie. Can. J. Plant Sci. 53:659-663.

Debano, J.F., and J. Letey (eds.). 1969. Water-repellent soils. Proc. of the Symp. on water-repellent soils. Univ. of California. Riverside.

Farmer, V.C. 1978. Water on particle surfaces. pp. 405-448. In: The chemistry of soil constituents. Greenland, D.J. and Hayes, M.H.B. (eds.). John Wiley and Sons. Chichester.

Flory, E.L. 1936. Comparison of the environment and some physiological responses of prairie vegetation and cultured maize. Ecology 17:67-103.

Haynes, J.L. 1940. Ground rainfall under vegetation canopy of crops. J. Amer. Soc. Agron. 32:176-184.

Helvey, J.D., and J.H. Patric. 1965. Canopy and litter interception of rainfall by hardwoods of Eastern United States. Water Resour. Res. 1:193-206.

Howitt, R.W. 1988. Soil survey of the county of Beaver. Alberta Soil Survey Report No. 47. Alberta Research Council Open File Rep. 1987-4.

Johnston, A. 1961. Comparison of lightly grazed and ungrazed range in fescue grassland of southwestern Alberta. Can. J. Plant Sci. 41:615-622.

Johnston, A., J.F. Dormaar, and S. Smoliak. 1971. Long-term grazing effects on fescue grassland. J. Range Manage. 24:185-188.

Kittredge, J. 1948. Forest influences. McGraw-Hill Book Co., New York, N.Y.

Kittredge, J. 1955. Litter and forest floor of the chapparral in parts of the San Dimas Experimental Forest. Hilgardia 23:563-596.
Kjearsgaard, A.A., W. Peters, and W.W. Pettapiece. 1982. Soil survey of the County of Newell No. 4, Alberta. Alberta Institute of Pedology Rep. S-82-41.

Lowdermilk, W.C. 1930. The influence of litter on run-off, percolation, and erosion. J. Forest. 28:474-491.

McCalla, T.M. 1943. Microbiological studies of the effect of straw used as a mulch. Trans. Kansas Acad. Sci. 43:52-56.

McCalla, T.M. 1944. Changes in the physical properties of straw during the early stages of decomposition. Soil Sci. Soc. Amer. Proc. 8:258-262.

McKeague, J.A. 1978. Manual on soil sampling and methods of analysis. Can. Soc. Soil Sci.

Naeth, M.A. 1985. Ecosystem reconstruction and stabilization following pipeline construction through solonetzic native rangeland in southern Alberta. M.Sc. Thesis. Univ. of Alberta. Edmonton.

Naeth, M.A. 1988. The impact of grazing on litter and hydrology in mixed prairie and fescue grassland ecosystems of Alberta. Ph.D. Diss. Univ. of Alberta, Edmonton.

Norman, A.G. 1933. The natural decomposition of plant materials. Sci. Prog. 27:470-485.

Pavlick, L.E., and J. Looman. 1984. Taxonomy and nomenclature of rough fescues, Festuca altaica, Festuca campestris ( $F$. scabrella var. major), and Festuca hallii, in Canada and the adjacent part of the United States. Can. J. Bot. 62:1739-1749.

Shapiro, S.S., and M.B. Wilk. 1965. An analysis of variance test for normality (complete samples). Biometrika 52:591-611.

Steel, R.G.D., and J.H. Torrie. 1980. Principles and procedures of statistics: a biometrical approach. 2nd ed. McGraw-Hill, New York.

Thurow, T.L., W.H. Blackburn, S.D. Warren, and C.A. Taylor Jr. 1987. Rainfall interception by midgrass, shortgrass, and live oak mottes. J. Range Manage. 40:455-460.

Weaver, J.E., and N.W. Rowland. 1952. Effects of excessive natural mulch on development, yield, and structure of native grassland. Bot. Gaz. 114:1-19.

Zeller, D.H. 1963. Certain mulch and soil characteristics in major range sites in western North Dakota as related to range condition. M.Sc. Thesis. North Dakota State Univ. Fargo. 